TOMASZ KASPRZAK

\author{
$\stackrel{\circ}{\|}$

\section{TOŻSAMOŚĆ MŁODZIEŻY WIETNAMSKIEGO POCHODZENIA W REPUBLICE CZESKIEJ}

\begin{abstract}
Tomasz Kasprzak, Tożsamość młodzieży wietnamskiego pochodzenia w Republice Czeskiej [Identity of youth Vietnamese descent in the Czech Republic] edited by E. Smolarkiewicz, J. Kubera, "Człowiek i Społeczeństwo" vol.XLIV: Tożsamośći identyfikacje. Propozycje teoretyczne-doświadczenia badawcze [Identity and identifications. Theoretical proposals - research experiences], Poznań 2017, pp. 151-164, Adam Mickiewicz University. Faculty of Social Sciences Press. ISSN 0239-3271.
\end{abstract}

The article presents an image of the identity of young Vietnamese living in the Czech Republic. After the dissolution of Czechoslovakia, most of the Vietnamese were left, and over time this minority started to grow (now they number more than 57,000 people). Multivariate social transformations, manifested in the continuous creation of the modern world, contribute to the difficulty of capturing and unambiguously identifying the notion of identity. Identity is primarily a social phenomenon, is closely related to values accepted in a given society, is present in its culture, and is strongly rooted in social consciousness. Multidimensional and multidimensional identity undoubtedly shapes the problem of self-awareness among Vietnamese youth.

Tomasz Kasprzak, Uniwersytet im. Adama Mickiewicza w Poznaniu, Instytut Socjologii, ul. Szamarzewskiego 89c, 60-658 Poznań, e-mail: tomasz.kasprzak@amu.edu.pl

[...] jesteśmy nie tym, czym jesteśmy, ale tym, co z siebie zrobimy

(Giddens 1991: 102)

\title{
Wstęp
}

Tożsamość migrantów i ich dzieci jest ważnym tematem obecnych debat dotyczących integracji tej grupy. Wietnamczycy są jedną z najsilniejszych wspólnot imigrantów w większości krajów postsowieckich. W takich 
państwach jak Czechy, Słowacja oraz Polska stanowią największą grupę obcokrajowców pochodzących z Azji. W Polsce Wietnamczycy są prawdopodobnie drugą pod względem liczebności wspólnotą cudzoziemców w 2012 r. było ich około 30 tys. (Piłat i Wysieńska 2012: 65). Choć ich obecność została zauważona przez badaczy zajmujących się kwestią imigracji w krajach środkowoeuropejskich, to problem ten bardzo rzadko pojawia się w publikacjach naukowych. Wietnamska mniejszość jest słabo zbadana pod względem mobilności transnarodowej kształtowanej przez politykę z czasów zimnej wojny. W okresie komunizmu napływ cudzoziemców do Czechosłowacji czy Polski był ograniczony i starannie kontrolowany przez państwo. W rezultacie po upadku komunizmu w krajach bloku wschodniego zamieszkiwało niewiele grup migrantów w porównaniu z państwami Europy Zachodniej. W literaturze poświęconej problematyce migracji upadek komunizmu kojarzy się z momentem, w którym zaczęła się mobilność międzynarodowa na dużą skalę.

Punktem wyjścia do napisania tekstu była analiza czeskiej literatury przedmiotu, w której niejednokrotnie po 1993 r. podejmowano kwestie migracji Wietnamczyków (Brouček 2003; 2003; Kocourek 2001, 2008; Martínková 2006). Podkreśla się, że istnieją różnice w percepcji tożsamości i procesach identyfikacji imigrantów pierwszej generacji. Obecnie „dzieci migrantów” nie są imigrantami, mimo iż termin „migranci drugiej generacji” jest powszechnie używany. Wielu z tych młodych ludzi urodziło się w Republice Czeskiej lub przyjechało do niej w bardzo młodym wieku. Przeszli przez czeski system edukacji, opanowali język, tworzą przyjaźnie, są mniej lub bardziej zintegrowani z ogółem społeczeństwa czeskiego. Dlatego wielu z nich uważa, że w odróżnieniu od ich rodziców pochodzenie etniczne nie powinno mieć dla nich znaczenia. W dyskursie politycznym potomkowie imigrantów są prezentowani jako problematyczna grupa - „uwikłana między dwiema kulturami” lub jako „pośrednicy kultur” (Svobodová i Janská 2016).

Na podstawie badań przeprowadzonych w latach 2012 i 2014 szacuje się, że w Republice Czeskiej mieszka około 57 tys. Wietnamczyków i są trzecią co do wielkości wspólnotą imigrantów w tym kraju. Natomiast dzieci i młodzież (do 26 lat) wietnamskich imigrantów - zarówno tych urodzonych w Wietnamie, jak i urodzonych w Czechach, stanowią 40\% całej populacji (Kušniráková 2014: 740). Obecnie przeprowadzono niewiele badań dotyczących tożsamości wietnamskich dzieci i młodzieży w Czechach. Istniejące badania koncentrowały się przede wszystkim na edukacji tych osób. 


\section{Wietnamczycy w Republice Czeskiej}

Jak podkreśla Šárka Martínková (2006: 85), początki stosunków między Czechosłowacją a Wietnamem można datować na lata pięćdziesiąte ubiegłego wieku, po utworzeniu Demokratycznej Republiki Wietnamu, gdy Czechosłowacja stała się tymczasowym schronieniem dla wietnamskich sierot wojennych. Wietnamska imigracja do byłej Czechosłowacji i obecnej Republiki Czeskiej ma długą tradycję i można ją podzielić na dwa okresy. Pierwszy - przed 1989 r. - charakteryzował się migracją regulowaną umowami międzynarodowymi. Czechosłowacja, podobnie jak inne kraje bloku wschodniego, podpisała umowy z Wietnamem o tymczasowej imigracji ludności. W latach pięćdziesiątych podpisano umowy dotyczące studiowania młodzieży wietnamskiej, natomiast w latach siedemdziesiątych odnoszące się do kształcenia zawodowego (Kocourek 2001). W latach osiemdziesiątych z kolei podpisano umowę w sprawie migracji zarobkowej. Kwestia ta stała się bardzo ważna dla kolejnych napływów imigrantów do Czechosłowacji - przede wszystkim do firm produkcyjnych. W latach 1979-1985 Wietnamczycy uczestniczyli w nieformalnych działaniach, które wynikały z niedoborów pracowników na czeskim rynku pracy. Celem wietnamskiego rządu było przywrócenie wykwalifikowanej siły roboczej z Czechosłowacji do ogarniętego wojną Wietnamu, aby pomóc w odbudowie kraju ${ }^{1}$.

Drugi okres - po 1989 r. - charakteryzował się głównie transformacją ustrojową. Na początku lat dziewięćdziesiątych nastąpił krótki okres niepewności co do sposobu współpracy Wietnamu z Czechosłowacją, później z Republiką Czeską. W wyniku rozwiązania w 1990 r. umów międzynarodowych między Czechosłowacją a Wietnamem nastąpiło przejściowe zerwanie stosunków czesko-wietnamskich. W 1994 r. podpisano traktat o profesjonalnym kształceniu obywateli Wietnamu w Republice Czeskiej oraz o wzajemnym zatrudnieniu. Od 2006 r. liczba wietnamskich migrantów pracujących na podstawie umów o pracę znacząco wzrosła, a większość z nich zatrudniona była jako pracownicy fizyczni (Martínková 2006).

${ }^{1}$ Władze wietnamskie pozwoliły na wyjazdy swoich obywateli od początku lat siedemdziesiątych ubiegłego wieku. Kierowali się oni wyłącznie do państw bloku wschodniego. Dzięki temu Wietnam poradził sobie z wysokim w tamtych latach bezrobociem. Wietnamczycy zdobyli doświadczenie, a także byli „tanią” siłą roboczą. 
Od początku lat dziewięćdziesiątych możemy mówić o powstaniu społeczności wietnamskiej, która jest w stanie ciągłej transformacji. Po rozpadzie Czechosłowacji w 1993 r. wietnamscy sklepikarze wynajmowali stoiska na targach (ta forma sprzedaży była nie tylko najtańsza, ale też najczęściej spotykana w Wietnamie). Sprzedawali głównie tekstylia, sprzęt elektryczny i artykuły spożywcze. Wietnamczycy osiedlali się w miejscach obiecujących najwyższe zyski, zaczęli pojawiać się w dużych miastach (Praga, Brno, Ostrawa) oraz w regionach przygranicznych (Český Těšín, Cheb, Železná Ruda, Potucky). Wietnamczycy należą obecnie do najszybciej rozwijających się grup migrantów w Czechach. Wietnamska imigracja do Republiki Czeskiej to głównie Wietowie ${ }^{2}$ pochodzący z obszarów wiejskich oraz większych miast północnego Wietnamu, z prowincji Nghe An, Ha Tinh, Hung Yen, Hai Duong oraz delty Rzeki Czerwonej (Martínková 2006).

Motywacja Wietnamczyków do zamieszkania w Republice Czeskiej znacznie ewoluowała z biegiem czasu ${ }^{3}$, jednakże najważniejszym, jak się wydaje, czynnikiem jest kwestia ekonomiczna (Brouček 2003: 121). Dorośli Wietnamczycy uważają, że żyje im się lepiej w Czechach aniżeli w Wietnamie, jednakże muszą pokonać wiele przeszkód, tj. przezwyciężyć tzw. „szok kulturowy”, poczucie separacji od rodziny pozostawionej w Wietnamie, problemy z przedłużeniem pobytu. Opierając się na definicji pojęcia mniejszości narodowej, zgodnie z ustawą nr 273/2001 o prawach mniejszości narodowych (zákon 273/2001 Sb. právech př́islušníků národnostních menšin), Wietnamczycy mieszkający w Republice Czeskiej nie są określani jako mniejszość narodowa, ale jako cudzoziemcy. Prowadzi to do ograniczeń, szczególnie w dziedzinie edukacji, kultury i dostępu do informacji w języku ojczystym. Jednocześnie polityka integracyjna Republiki Czeskiej wobec Wietnamczyków nie jest kwestią priorytetową. Wietnamczycy występują także o ochronę międzynarodową oraz możliwość studiowania na czeskich uczelniach. Wietnamska młodzież marzy

2 Wietowie (Wietnamczycy) stanowią podstawową część ludności Wietnamu (71 mln osób), a poza jego granicami zamieszkują w Laosie, Kambodży, Chinach, Stanach Zjednoczonych oraz w państwach Europy Środkowej i Wschodniej (m.in. Czechy, Polska, Słowacja).

3 W latach sześćdziesiątych i siedemdziesiątych ubiegłego wieku do Czechosłowacji przybywali głównie młodzi, samotni mężczyźni pracujący w przemyśle. W latach osiemdziesiątych można było zauważyć znaczny wzrost liczby młodych Wietnamczyków przyjeżdżających na studia. Po 1993 r. do Republiki Czeskiej przybywały też kobiety, a nawet następowało łączenie rodzin. 
o studiowaniu za granicą, aby zapewnić sobie wysoką jakość edukacji w dziedzinach, które nie są dostępne w Wietnamie. Rząd czeski oferuje stypendia dla wietnamskich utalentowanych studentów, większość jednak podejmuje studia na własny koszt, nie licząc na pomoc rządu czeskiego. Niektóre czeskie uczelnie podpisały umowy partnerskie z wietnamskimi uczelniami (np. Uniwersytet w Ostrawie ma umowy partnerskie z dwunastoma uczelniami w Wietnamie). Dla zamożniejszych Wietnamczyków studia za granicą są rozwiązaniem, gdy nie dostaną się na krajowe uniwersytety.

Społeczność Wietnamska w Republice Czeskiej podzielona jest na trzy odrębne grupy - w zależności od czasu przyjazdu do tego kraju. Pierwsza to grupa tzw. „starców” (czes. starousedlíků). Do Czechosłowacji przybyli w latach osiemdziesiątych XX w. Ich przyjazd uzależniony był od międzynarodowych porozumień. Rozmieszczeni zostali na terenie całej Czechosłowacji, mieszkali w schroniskach i ze względu na surowe warunki oddzieleni byli od reszty społeczeństwa. Przed 1989 r. Wietnamczycy przyjeżdżający do Czechosłowacji pochodzili zazwyczaj z zamożnych rodzin, w których wyjazd za granicę był przywilejem. Zaraz po przyjeździe uczestniczyli w trzymiesięcznym kursie języka czeskiego - wielu znało ten język (lepiej lub gorzej) przed przyjazdem. Należy pamiętać, że po zniesieniu międzynarodowych porozumień grupa została zmuszona do opuszczenia kraju i powrotu do Wietnamu. Druga grupa, która przybyła do Czech w latach dziewięćdziesiątych ubiegłego wieku, nazywana jest „postrewolucyjną” (czes. porevoluční). W tym okresie zmienił się charakter wyjazdu Wietnamczyków do Czech. Z Wietnamu zaczęły wyjeżdżać osoby z małych miejscowości oraz wiosek, które opłacały swój wyjazd za pomocą pośredników. Przybywali także Wietnamczycy z sąsiednich krajów, takich jak Niemcy oraz Polska. W latach 1990-1992 rozpoczęto reformy czeskiego/czesko-słowackiego systemu politycznego. Ustanowiono odpowiednie instytucje i organy na rzecz migracji, procesy migracyjne skoordynowano z nowym prawodawstwem i konkretnymi programami. Trzecia grupa, tzw. „świeża fala” (czes. Čerstvá vlna migrantů), to Wietnamczycy przybyli do Czech po roku 2000, określani jako „druga generacja” wietnamskiej migracji (Pechová 2007).

Obecnie Wietnamczycy w Republice Czeskiej powiązani są przede wszystkim rodzinnie, sąsiedzko, towarzysko oraz w ramach własnych organizacji. Największą i najstarszą z nich jest „Społeczność czesko-wietnamska” (czes. Česko-vietnamské společnost). Organizacja współpracuje z czeskimi władzami, a jej podstawowym celem jest pomoc Wietnamczykom i pełne włączenie ich do czeskiego społeczeństwa. 


\section{Tożsamość - próba definicji}

Pojmowanie tożsamości (ang. identity) w odniesieniu do człowieka w kontekście jego samoświadomości i egzystencji pojawiło się w XIX w. za sprawą Williama Jamesa. Mimo refleksji nad tożsamością prowadzonej w latach dwudziestych i trzydziestych XX stulecia m.in. przez George’a H. Meada i Charlesa Cooleya, powszechnie termin ten zaczął obowiązywać dopiero w połowie XX w. Upowszechnienie pojęcia tożsamości przypisuje się Erikowi H. Eriksonowi, który rozważał i badał tożsamość już w latach czterdziestych XX w. Rozumiał on tożsamość różnie, podkreślając następujące konotacje tego pojęcia: (1) jako świadome poczucie samego siebie; (2) jako dążenie do ciągłości osobistego charakteru; (3) jako milczące realizowane syntezy ego; (4) jako wewnętrzna solidarność z ideałami i własnościami grupy (Golka 2006: 9-11). Autor na gruncie uprawianej przez siebie psychoanalizy socjologicznej rozwinął idee tożsamości psychospołecznej. Opracował fazy rozwoju tożsamości jednostki i związane z nimi kryzysy w sferze tożsamości (Kociuba 2007: 54). Problem tożsamości pojawił się w związku z gwałtowną zmianą w społeczeństwie przemysłowym. Nastąpiła wówczas istotna transformacja form życia zbiorowego i życia jednostek w Europie Zachodniej (Kociuba 2007: 53). Tożsamość jako problem pojawia się w warunkach modernizacji, kiedy rzeczywistość tego świata ulega podważeniu.

Tożsamość oznacza świadomość siebie, zdolność określenia, kim się jest, do jakiej grupy się należy, z jaką grupą człowiek się identyfikuje i do jakiej się przyznaje (Budyta-Budzyńska 2013: 91). Jak podkreśla Antonina Kłoskowska (2005: 99), pojęcie tożsamości „określa refleksyjny stosunek podmiotu wobec samego siebie”. Maria Jarymowicz (1989: 73) stwierdza, że tożsamość „to posiadane przez podmiot wizje własnej osoby, a dokładniej wizje tego co dla autocharakterystyki najważniejsze, najbardziej charakterystyczne i specyficzne”. Tożsamość definiowana jest często jako względnie trwała struktura uczuć, wartości i przedstawicieli (reprezentacji) odnoszących się do siebie. Anita Jacobson-Widding (1983: 13) zwraca uwagę na istotne cechy tego pojęcia. Tożsamość jest kontynuacją, pozostawaniem tym samym (ang. sameness) i jednocześnie odnosi się do odrębności, odróżniania się (ang. distinctiveness). Dariusz Wojakowski (2007: 86) podsumowuje, że „istnieje pewna jednolita ontologiczna koncepcja tożsamości, na którą składają się trzy proste tezy”: (1) tożsamość jest elementem świadomości jednostki; (2) tożsamość jest „produktem” uczestniczenia jednostki 
ujmowanej jako podmiot w społecznych interakcjach; (3) tożsamość wyraża się w werbalnych strukturach symbolicznych. Anthony Giddens (1991: 52) wiąże tożsamość z ontologicznym i egzystencjalnym bezpieczeństwem. Własna tożsamość w ujęciu Giddensa nie jest czymś gotowym, danym, ale czymś zdobywanym, tworzonym i utrzymywanym poprzez refleksyjne działania podmiotu.

Wielość sposobów rozumienia pojęcia tożsamość, mieszcząca się w intensywnie gromadzonym dorobku różnych dyscyplin przez ponad pięćdziesiąt lat, czyni trudnym uporządkowanie tej materii. Powstały rozmaite koncepcje tożsamości, a także różne sposoby typologizacje tego pojęcia. Definicja przyporządkowana jest albo sferze uczuć, emocji, albo sferze wiedzy, samowiedzy, sfer poznawczych człowieka (Borowik i Leszczyńska 2007: 9). Socjologiczna interpretacja tożsamości, jej genezy, natury i funkcji związana jest ściśle z koncepcją zmiany, rozwoju, postępu społecznego i kulturowego (Paleczny 2008: 25).

\section{„Bananowe dzieci" - młodzież wietnamska w Republice Czeskiej}

W Republice Czeskiej kształci się około 2\% uczniów (Český statistický úrad 2014), dla których język czeski jest językiem obcym. Wielu z nich rozpoczyna naukę z niewielką lub żadną znajomością języka czeskiego. W Czechach wszystkie dzieci mają zagwarantowane prawo do edukacji na poziomie podstawowym. W praktyce oznacza to, że nawet dzieci z obcym obywatelstwem mają takie same prawa jak ich czescy rówieśnicy. Prawa te wynikają z Konwencji o prawach dziecka (czes. Úmluva o právech dítěte), ustawy nr 541/2004 o edukacji na poziomie przedszkolnym, podstawowym, średnim oraz zawodowym, a także ustawy nr 326/1999 o pobycie cudzoziemców w Republice Czeskiej. Ten ostatni przepis reguluje warunki wjazdu cudzoziemca na terytorium kraju oraz określa, kto jest cudzoziemcem. Ustawa dzieli cudzoziemców na dwie kategorie: obywateli z państw Unii Europejskiej oraz obywateli spoza Unii Europejskiej (tzw. państw trzecich).

Edukacja uczniów-cudzoziemców jest jednym z istotnych obszarów kompetencji Ministerstwa Edukacji, Młodzieży i Sportu (czes. Ministerstvo školství, mládeže a tělovýchovy České republiky). Ministerstwo to od 2000 r. prowadzi systematyczne kształcenie w ramach koncepcji integracji cudzoziemców. Uczestnictwo w szkoleniu jest obowiązkowe dla wszystkich dzieci nieposiadających czeskiego obywatelstwa. Głównym zadaniem 
programu jest przede wszystkim nauczenie języka czeskiego, usunięcie barier komunikacyjnych oraz integracja uczniów różnych narodowości z rówieśnikami i resztą społeczeństwa. Dodatkowo szkoły mogą również wykorzystać ustawę nr 147/2011 o kształceniu uczniów ze specjalnymi potrzebami edukacyjnymi (czes. Vyhláška o vzdělávání žáků se speciálními vzdělávacími potřebami a žáků nadaných), na podstawie której nauczyciel może zintensyfikować proces nauczania ucznia z niedostateczną znajomością języka czeskiego (w porównaniu z innymi uczniami w klasie).

W wielu czeskich publikacjach ${ }^{4}$ znaleźć można określenie „bananowe dzieci” (czes. banánové děti), które odnosi się do dzieci wietnamskich urodzonych w Republice Czeskiej lub mieszkających w tym kraju od dzieciństwa. Urodą wskazują na swoje wietnamskie pochodzenie, jednak styl życia i wartości wyznawane przez nich znajdują odzwierciedlenie w zachowaniu ich czeskich rówieśników. Wietnamskie dzieci są zwykle przedstawiane jako bardzo sumienne, uzyskują bardzo dobre wyniki we wszystkich typach szkół i w przeciwieństwie do wietnamskiej klasy średniej, są bardzo dobrze zintegrowane z większością społeczeństwa. Mówią doskonale po czesku, mają wielu czeskich przyjaciół, natomiast kultura i język Wietnamu są im obce.

Martínková (2010: 39-40) wyróżnia dwie podstawowe grupy „bananowych dzieci”, które znacząco różnią się między sobą. Pierwsza grupa składa się przede wszystkim z tych osób, które przyjechały do Czech w latach dziewięćdziesiątych i razem ze swoimi rodzicami doświadczyły trudnych początków emigracji. Są w pełni świadome ciężkiej pracy i wyrzeczeń swoich rodziców, co silnie odzwierciedla nabyte przez nie wartości i postawy. Druga grupa składa się z osób, które urodziły się w Czechach lub dorastają w tym kraju od najmłodszych lat. Nie mają związku kulturowego z Wietnamem i nie chcą porozumiewać się w języku wietnamskim. Głównym problemem, który pojawia się w tej grupie, jest kwestia języka ojczystego. Wiele z nich nigdy nie uczyło się języka wietnamskiego lub się go wstydzi. Wynika to głównie z faktu, że uczęszczają do czeskich szkół, w których porozumiewają się po czesku. Bardzo często ich rodzeństwo mówi głównie po czesku, a jedyny kontakt z językiem wietnamskim mają dzięki rodzicom.

${ }^{4}$ Więcej na temat „bananowych dzieci” zob.: Tuček 1998; Kocourek 2001, 2006; Klapko 2008; Martínková 2010.

${ }^{5}$ Ten termin nie jest irytujący dla dzieci i nastolatków z rodzin wietnamskich. Większość z nich nie postrzega go pejoratywnie. Określenie „dzieci bananowe” w sposób metaforyczny odnosi się do faktu, iż kolor skóry mają ,żółty” - co symbolizuje ludność Wietnamu, ale wewnątrz są „,białe” - zachowują się jak Czesi. 
Są jednak przypadki, kiedy rodzice też mówią po czesku, pomimo średniej znajomości tego języka.

Dla młodych Wietnamczyków najważniejszym celem w życiu jest edukacjaco jest charakterystyczne dla całej społeczności wietnamskiej. Motywacja do nauki wietnamskich dzieci jest na ogół wyższa niż ich czeskich rówieśników. Wietnamscy rodzice znani są ze swoich nacisków na prawidłowe wychowanie dzieci. Jeśli odnoszą sukcesy, nie jest dla nich problemem zainwestować pieniądze w edukację dzieci i wysłać je za granicę - najczęściej do państw Europy Zachodniej i Stanów Zjednoczonych (Bittnerová i Moravcová 2006: 335). Wśród dorosłych Wietnamczyków szacunek do edukacji i wykształcenia wywodzi się z chińskiego konfucjanizmu. W społeczeństwie wietnamskim nadal nacisk położony jest na konfucjańskie wartości. Podobnie jak w większości innych kultur azjatyckich, chodzi przede wszystkim o poszanowanie rodziców i osób starszych. Typowe jest utrzymanie hierarchii społecznej. Edukacja jest zatem ważnym obszarem, w którym młodzi Wietnamczycy integrują się z czeskim społeczeństwem, uczą się czeskich zwyczajów i tradycji. Młodzi mieszkają w dużych rodzinach, które bardzo często składają się z dalekich ciotek i wujków, także posiadających potomstwo. Ojciec ma największy autorytet w rodzinie, a dzieci muszą być mu posłuszne (Černik 2006: 164).

\section{Tożsamość w kontekście wielokulturowości}

Problematyka tożsamości w kontekście wielokulturowości podejmowana jest przez badaczy wielu dyscyplin - jest przedmiotem zainteresowania socjologii (uczestnictwo jednostek w różnych grupach kulturowych), psychologii społecznej (samoidentyfikacja etniczna) czy historii (Kornacka-Skwara 2011: 113). Odmienność kulturowa - zaczynając od językowej, religijnej, a kończąc na obyczajowej - jest powodem wielu różnic, podobnie jak kolor skóry, miejsce urodzenia, nazwisko, narodowość czy obywatelstwo. Kultura staje się przede wszystkim atrybutem jednostki, a nie grupy. W tym kontekście dla młodzieży kultura stanowi coś w rodzaju supermarketu, zawierającego wszystkie możliwe wytwory kultury materialnej i duchowej w skali globalnej (Paleczny 2008: 35). Młodzież żyje poprzez „stylistyczne afiliacje” (Melosik 2016: 76). Jak podkreśla Andy Bennett (2007: 23), zasadne w przeszłości dostrzeganie tożsamości jako konsekwencji klasowego, rasowego, płciowego czy zawodowego usytuowania jednostki nie jest dziś uprawomocnione. Młodzi ludzie, jak podkreśla Zbyszko Melosik (2016: 77), 
przyjmują „wybraną i tymczasową rolę lub tożsamość”, by następnie „przemieścić się do alternatywnego miejsca i przyjąć odmienną tożsamość”.

Współczesna młodzież w znacznie mniejszym stopniu potrzebuje długotrwałych, pogłębionych i autentycznych relacji. Typowa dla przeszłości jedna „wielka tożsamość” została zastąpiona przez wielość „małych tożsamości” - zmieniających się pod wpływem postępującej zmiany (pop) kulturowej. „Małe tożsamości” mają krótkotrwały i powierzchowny charakter, pozbawione są w większości oczekiwań i wielkich rozczarowań. Współczesne relacje oparte są na zasadzie „przeskakiwania” z relacji do relacji. Ich liczba zwiększa się, tworząc nadmiar kontaktów w naszym życiu. We współczesnym społeczeństwie mamy coraz częściej do czynienia z relacjami typu „fast food” - spreparowanymi, określonymi przez wzory krótkotrwałych relacji (Melosik 2016: 82).

Tożsamość w kontekście wielokulturowym jest z natury rzeczy samoświadomością jednostki. Tożsamość, pomimo że jest zjawiskiem uniwersalnym i powszechnym, koncentruje się na realnym kontekście społecznym. Zawiera elementy duchowe, intelektualne, wyznaczniki płciowe, rasowe, etniczne oraz narodowe. W budowaniu tożsamości młodzież wietnamska w Republice Czeskiej wystawiona jest na różne wpływy - z jednej strony na wpływ rodziców, a z drugiej - społeczeństwa czeskiego (m.in. rówieśnicy, przyjaciele, nauczyciele). Sytuacja ta powoduje powstawanie wątpliwości co do własnej tożsamości. Vladislava Heřmanová (2006: 93) nazywa to utratą tożsamości, gdyż jednostka pod wpływem różnych czynników nie może rozpoznać własnego „Ja”, co może prowadzić do kryzysu tożsamości i poczucia niepewności.

Rodzice młodych Wietnamczyków w większości mają silne związki z Wietnamem, wymagając często od swoich dzieci przestrzegania tradycyjnych wietnamskich wartości i wzorców zachowań, tj. posłuszeństwa, rodzinnej solidarności oraz pokory. W ten sposób rodzice wprowadzają w życie reguły i normy postępowania, których nie można wykorzystać w czeskim kontekście. Może to prowadzić do poczucia wewnętrznego konfliktu, gdy osoby nie wiedzą, kim są i do jakiego społeczeństwa przynależą (Martínková 2010: 33). Wśród czynników wpływających na tożsamość dzieci imigrantów wyraźnie podkreśla się społeczne role rodziców, wsparcie społeczne rodziny, a także rodzaj szkoły, do której uczęszcza dziecko. Wielu młodych Wietnamczyków odczuwa różnice kulturowe ze względu na sposób prowadzenia życia rodziców. Większość wietnamskich dzieci wychowywały babcie lub ciotki i to one, zaraz po rodzicach, przekazywały wietnamskie tradycje i zwyczaje (Martínková 2010). Jak zauważa Martínková (2010: 3), 
„młodym Wietnamczykom jest bliżej do stylu życia czeskiego społeczeństwa, jednakże zmuszeni są do przestrzegania zachowań akceptowalnych przez wietnamską tradycję”. „Bananowe dzieci” są świadome, że żyją w podwójnej rzeczywistości; jak same podkreślają: „żyjemy w podwójnym świecie, w dwóch odmiennych kulturach”. Młodzi Wietnamczycy poszukują swojego „prawdziwego Ja”, które będzie nienaruszone i nieskażone zewnętrznymi naciskami. Pragną odkryć swoją indywidualność w życiu zdominowanym niepewnością. Młodzi żyją, jak określa to Zygmunt Bauman, w „płynnej tożsamości”. Muszą ,„pogodzić się z tym, że tożsamość może istnieć jedynie jako niedokończony projekt” (Bauman 2006: 46). Okres walki o identyfikację z kulturą ich rodziców i kulturą kraju, w którym dorastają, to tylko jeden z etapów ich życia, kiedy to ich uczucia i opinie na swój temat rozwijają się oraz zmieniają wraz z upływem czasu.

Rozumienie tożsamości jako czegoś zbudowanego społecznie, płynnego oraz zmiennego w czasie odpowiada konstruktywistycznej perspektywie dotyczącej rozwoju tożsamości. Perspektywa ta jest często przedstawiana w opozycji do perspektywy esencjalizmu, która postrzega tożsamość jako coś ulotnego, nadanego biologicznie, wszechobecnego, czekającego na odkrycie. Obie perspektywy rozumieją tożsamość jako coś niestabilnego i rozwijającego się w czasie. Różnica polega na tym, że z punktu widzenia esencjalistów (zob. Erikson 1974) ten niestały proces osiąga stałe miejsce. Z postmodernistycznego punktu widzenia (zob. Bauman 2006; Berger i Luckmann 1991) nigdy nie może mieć to miejsca. Rozwój tożsamości młodzieży wietnamskiej w Republice Czeskiej możemy podzielić na cztery okresy (Svobodová i Janská 2016: 125-130):

1. okres „błogosławionej nieświadomości” - etap wczesnego dzieciństwa, kiedy dziecko nie zdaje sobie sprawy z jakichkolwiek różnic. Dzieci mają bardzo wielu czeskich znajomych, spędzają z nimi wiele czasu (głównie w szkole). Okres kończy się w fazie wczesnego dojrzewania (między 13. a 15. rokiem życia), kiedy dzieci zdają sobie sprawę, że są inne i zaczynają zadawać sobie pytania, czy są Wietnamczykami czy Czechami;

2. okres „odrzucenia etnicznej różnicy” - młodzi coraz częściej dostrzegają różnice między życiem Wietnamczyków i Czechów. Rodzice zaczynają przekazywać tradycyjne wartości wietnamskie. Okres ten charakteryzuje się konfliktami z rodzicami o to, co jest akceptowane w społeczeństwie czeskim, ale zakazane przez wietnamską społeczność;

3. okres „odrodzenia etnicznego” - odnowione zainteresowanie etnicznością i kulturą rodziców oraz zmiana kręgu społecznego. W tym okresie młodzież sięga do korzeni swojego pochodzenia, zanurza się w języku i kulturze 
Wietnamu. Częściowo wynika to z presji rodziców. Tworzone są nowe przyjaźnie i umacniane stare relacje z przyjaciółmi pochodzenia wietnamskiego;

4. okres, który można określić jako „podwójna tożsamość vs zażenowanie i złość na obie kultury”. Rozwój tożsamości wietnamskiej młodzieży nie kończy się na etapie „odrodzenia etnicznego”. Młodzi zdają sobie sprawę, że mają wybór, że mogą reprezentować wiele tożsamości, które mogą mniej lub bardziej swobodnie i selektywnie ujawniać w zależności od sytuacji. Tworzą poczucie własnej wyjątkowości, widzenia świata z perspektywy dwóch kultur.

Dla wietnamskiej młodzieży mieszkającej w Czechach dorastanie oznacza nie tylko konieczność sprostania różnym oczekiwaniom rodziców, ale także poradzenia sobie z uprzedzeniami i stereotypami. Niewątpliwie, sposób postrzegania młodych Wietnamczyków przez czeskie społeczeństwo ma wpływ na rozwój ich tożsamości. Wietnamska młodzież bardzo często postrzegana jest przez pryzmat handlarzy narkotyków czy przestępców, którzy wywodzą się z „konserwatywnego i mniej rozwiniętego” społeczeństwa wietnamskiego. Społeczność wietnamska w Czechach przedstawiana jest jako zamknięta oraz „niekomunikowalna”; ma problemy z wynajmem mieszkania; spotyka się z zachowaniami agresywnymi ze strony niektórych Czechów. Młodzi Wietnamczycy chcący podjąć pracę w Czechach muszą się liczyć z licznymi problemami, do których należą: bariery kulturowe, brak możliwości znalezienia pracy bez pośrednika spoza społeczności wietnamskiej, niejasne procedury w ustanawianiu stosunku pracy (tj. opłaty mediacyjne, brak informacji o prawach pracownika), niewypłacanie wynagrodzenia na czas.

\section{Podsumowanie}

Do niedawna problem mniejszości wietnamskiej w krajach Europy Środkowej i Wschodniej nie był zbyt często poruszany w literaturze przedmiotu. Emigranci z Wietnamu przemieszczają się po całym świecie. Na podstawie oficjalnych danych Ministerstwa Spraw Zagranicznych Socjalistycznej Republiki Wietnamu około 4 mln ludzi opuściło kraj. Całkowita kwota przekazów pieniężnych wysyłanych przez mniejszość wietnamską w 2014 r. wyniosła 12 mld USD, co stanowi około 8\% PKB Wietnamu. Jeżeli porównamy młodzież wietnamską i pokolenie ich rodziców, możemy zauważyć różnice w stopniu integracji ze społeczeństwem czeskim. Starsze pokolenie żyje w zamkniętych społecznościach, często ma trudności w porozumiewaniu 
się po czesku, czuje tęsknotę za ojczyzną. Młodzi mówią bardzo dobrze po czesku pomimo wpajanej miłości do Wietnamu, wybierają kulturę i wartości czeskiego społeczeństwa. Ważnym czynnikiem wpływającym na ich integrację ze społeczeństwem są czeskie szkoły. Młodzi uczęszczają do czeskich szkół, chcą być akceptowani mimo dzielących ich różnic. Czescy badacze zjawiska wskazują na rosnący problem konfliktu międzygeneracyjnego w społeczności wietnamskiej.

W artykule poruszono aspekty postrzegania i formowania tożsamości wśród młodzieży pochodzenia wietnamskiego zamieszkującej Republikę Czeską. Celem rozważań było przede wszystkim pokazanie, w jaki sposób młodzi ludzie tworzą tożsamość, dorastając w „dwóch kulturach”. Tożsamość budowana jest i utrwalana w ciągu długich, złożonych oraz zmiennych interakcji. Tożsamość pozwala nam funkcjonować zarówno w zaciszu domowym, jak i w życiu społecznym (Paleczny 2008: 165). Specyfiką mniejszości wietnamskiej jest życie w ustawicznym poczuciu tymczasowości pobytu w Republice Czeskiej. Wpływa to negatywnie na motywację do nauki języka czeskiego, budowanie znajomości i przyjaźni z Czechami.

\section{Literatura}

Bauman Z. (2006), Płynna nowoczesność, przeł. T. Kunz, Kraków: Wydawnictwo Literackie.

Bennett A. (2007), As Young as You Feel. Youth as a Discursive Construct, w: P. Hopkinson, W. Deice (red.), Youth Cultures. Scenes, Subcultures and Tribes, New York: Routledge.

Berger P., Luckmann T. (1991), The Social Construction of Reality. A Treatise in the Sociology of Knowledge, Harmondsworth: Penguin Books.

Bittnerová D., Moravcová M. (2006), Etnické komunity v české společnosti, Praha: Ermat:.

Borowik I., Leszczyńska K. (2007), Wokół tożsamości - teorie, wymiary, ekspresje, Kraków: Zakład Wydawniczy „Nomos”.

Brouček S. (2003), Aktuální problémy adaptace vietnamskeho etnika w České republice, Praha: Etnologický ústav Akademi věd České republiky.

Budyta-Budzyńska M. (2013), Socjologia narodu i konfliktów etnicznych, Warszawa: Wydawnictwo Naukowe PWN.

Ciosek Z. (2014), Odkrywanie tożsamości narodowej poprzez budowanie dyskursu medialnego, „Łódzkie Studia Teologiczne” nr 24/1.

Černik J. (2006), S vietnamskými dětmi na českých školách, Praha: Jinočany H\&H.

Erikson E. (1974), Identity: youth and crisis. New York: Norton.

Giddens A. (1991), Modernity and Self-Identity: Self and Society in the Late Modern Age, Stanford: Stanford University Press.

Golka M. (2006), Czym bywa tożsamość? Kłopoty z tożsamościq̨: tyrania współczesności?, w: M. Golka (red.), Kłopoty z tożsamościq, „Człowiek i Społeczeństwo” vol. 26. 
Jacobson-Widding A. (1983), Identity: Personal and Sociocultural, Uppsala: Uppsala University.

Jarymowicz M. (1989), Spostrzegać samego siebie, „Studia Psychologiczne” nr 27/2.

Heřmanová V. (2006), Identita a psychologie, w: J. Balvín (red.), Identita ve vztahu k národnostním menšinám, Mezinárodní konferene: 5 setkání národnostních menšin, Praha: Komise Rady hl. m. Prahy pro oblast národnostních menšin.

Klapko D. (2008), Editor, kolektiv autorů: Symposium sociální pedagogiky na PdF MU, Brno: Masarykova univerzita.

Kłoskowska A. (2005), Kultury narodowe u korzeni, Warszawa: Wydawnictwo Naukowe PWN.

Kociuba J. (2007), Narracyjna koncepcja tożsamości, w: I. Borowik, K. Leszczyńska, Wokół tożsamości - teorie, wymiary, ekspresje, Kraków: Zakład Wydawniczy „Nomos”.

Kocourek J. (2001), Historie příchodu a působení příslušníků vietnamské národnosti na území ČSR (resp. ČSSR) v letech 1950 až 1975 (diplomová práce), Praha: Univerzita Karlova.

Kornacka-Skwara E. (2011), Tożsamość narodowa w świetle przemian kulturowych, Prace Naukowe Akademii im. Jana Długosza w Częstochowie, Seria Pedagogika t. 20.

Kušniráková T. (2014), Is There an Integration Policy Being Formed in Czechia?, „Identities Global Studies in Culture and Power” t. 21.

Martínková Š. (2006), Vietnamská komunita v Praze, Praha: Ministerstvo vnitra ČR.

Melosik Z. (2016), Post-subkultury i tożsamość młodzieży współczesnej: tyrania tymczasowości?, „Studia Edukacyjne” nr 39.

Paleczny T. (2008), Socjologia tożsamości, Kraków: Krakowska Szkoła Wyższa im. Andrzeja Frycza Modrzejewskiego.

Piłat A., Wysieńska K. (2012), Społeczności azjatyckie w Polsce oraz w wybranych krajach regionu i świata, w: K. Wysieńska (red.), Sprzedawać, gotować, budować? Plany i strategie Chińczyków i Wietnamczyków w Polsce, Warszawa: Instytut Spraw Publicznych.

Svobodová A., Janská E. (2016), Identity Development Among Young Youth of Vietnamese Descent in the Czech Republic, w: M.L. Seeberg, E.M. Goździak (red.), Contested Childhoods: Growing up in the Migracy, Springer Open.

Tuček M. (1998), Česká rodina v transformaci - Stratifikacie, dělba a hodnotově orientace, Praha: Sociologicky ústav Akademie věd České republiky.

Wojakowski D. (2007), Swojskość i obcość w zmieniajq̨cej się Polsce, Warszawa: Wydawnictwo IFiS PAN.

\section{Źródła internetowe}

Český statistický úřad - Národnostní struktura obyvatel (2014), https://www.czso.cz/documents/10180/20551765/170223-14.pdf [10.09.2017].

Kocourek J. (2008), Stručný historický přehled o česko-vietnamských vztazích a působení Vietnamců $v \breve{C} R$, http://www.asimilovani.estranky.cz/clanky/narodnosti-v-cr/vietnamci. html [10.09.2017].

Pechová E. (2007), Migrace z Vietnamu do České republikz v kontextu problematiky obchodu s lidmi a vzkořistování, La Strada Česká republika o.p.s., https://aa.ecn.cz/img_uploa d/224c0704b7b7746e8a07df9a8b20c098/Zprava_migrace_Vietnam.pdf [1.09.2017]. 